\title{
Serum levels of acute phase and cardiac proteins after myocardial infarction, surgery, and infection
}

\author{
F VOULGARI, P CUMMINS, T I M GARDECKI, N J BEECHING, P C W STONE, J STUART \\ From the Departments of Haematology, Cardiovascular Medicine, and Surgery, University of Birmingham, and \\ Department of Communicable and Tropical Diseases, East Birmingham Hospital, Birmingham
}

SUMMARY C-reactive protein and four other acute phase reactant proteins of non-cardiac origin (orosomucoid, alpha ${ }_{1}$ - antitrypsin, haptoglobin, and alpha ${ }_{2}$-macroglobulin) were studied serially by laser immunonephelometric assay in sera from 17 patients with myocardial infarction. A similar comparison was made in 57 patients undergoing surgery and 72 patients with acute infection. C-reactive protein was consistently the most sensitive acute phase reactant in all three conditions. After myocardial infarction, a raised serum C-reactive protein level was found on admission in fivr patients before a rise in creatine kinase $M B$ isoenzyme (CK MB). The peak C-reactive protein level was reached on the third post-infarct day and it then declined over seven days with a half-life similar to myocardial tropomyosin. Serial monitoring of serum C-reactive protein, in parallel with cardiac proteins of short half-life (CK MB) and long half-life (tropomyosin), provides maximal information for diagnosis and for detecting post-infarct complications.

Acute phase reactant proteins are synthesised by the liver in response to acute tissue damage. Serial estimation of these proteins, C-reactive protein in particular, ${ }^{1}$ has been used to monitor the progress of a variety of clinical disorders and the recent introduction of rapid assays, using laser immunonephelometric, ${ }^{2}$ rate immunonephelometric, ${ }^{3}$ and immunoradiometric ${ }^{4}$ techniques, will increase their clinical application.

The original observation ${ }^{5}$ that $\mathrm{C}$-reactive protein could be detected in serum after myocardial infarction was followed by a number of studies using semiquantitative immunoprecipitation techniques ${ }^{6-9}$ and, later, electroimmunoprecipitation ${ }^{10}$ and radial immunodiffusion ${ }^{11}$ assays. These studies, and a more recent immunoradiometric assay, ${ }^{4}$ indicate the potential clinical value of measuring acute phase reactants in serum after myocardial infarction. There is, however, a need to determine whether C-reactive protein estimation has advantages over other acute phase proteins for cardiac studies and to investigate the time course of its rise and fall in serum after myocardial infarction in comparison with proteins of cardiac origin. Laser immunonephelometric assays of $\mathrm{C}$-reactive protein and

Accepted for publication 29 June 1982 four other acute phase proteins (orosomucoid, alpha $a_{1}$ ه antitrypsin, haptoglobin, and alpha $_{2}$-macroglobulin) were therefore studied serially after myocardial infarction in comparison with a soluble, cytosolic myocardial enzyme (CK MB) and a structural protein of the cardiac myofibril (tropomyosin). ${ }^{12}$

\section{Patients and methods}

Sixty healthy adults, to give reference control values, and three groups of hospital in-patients were studied.

\section{MYOCARDIAL INFARCTION}

Seventeen patients were admitted to a coronary care $\frac{T}{0}$ unit with a typical history, and electrocardiographic and serum enzyme confirmation, of myocardial infarc- o tion. Patients were studied daily for $\mathbf{1 0}$ days using an $N$ indwelling forearm venous catheter, the time of onset $N$ of chest pain (day 1) being clearly established. Seven of the patients were studied every two hours for the first 24 hours.

SURGERY

Fifty-seven patients ( 33 undergoing hip replacement and 24 requiring herniorrhaphy) were admitted for elective surgery and studied on days 1 (day of operation), 4 , and 8. 
INFECTION

Seventy-two infected adult patients requiring admission to an infectious diseases unit were studied on days 1 to 3 of admission: all had laboratory confirmation of bacterial, viral, or protozoal ( $P$. vivax malaria) infection.

\section{ACUTE PHASE REACTANT PROTEINS}

Serum specimens were deep frozen $\left(-20^{\circ} \mathrm{C}\right)$ and assayed in batches using a Hyland Laser Nephelometer PDQ $^{\mathrm{TM}}$ (Travenol Laboratories, Thetford). ${ }^{2}$ Polyethylene glycol of molecular weight $\mathbf{4 0 0 0}$ was used for assay of C-reactive protein and haptoglobin, and of molecular weight 6000 for orosomucoid, alpha -

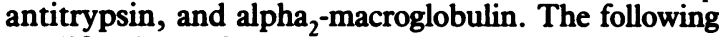
modifications of the $\mathrm{C}$-reactive protein method ${ }^{2}$ were required for the four other reactants.

\section{Antiserum}

Nephelometric grade goat antisera to orosomucoid, alpha ${ }_{1}$-antitrypsin, and alpha ${ }_{2}$-macroglobulin (Seward Immunostics, London), and rabbit antiserum to human haptoglobin (Dako Immunoglobulins, Copenhagen), were diluted respectively $1 / 100,1 / 40,1 / 50$, and $1 / 100$ in phosphate buffer and filtered through a $0.4 \mu \mathrm{m}$ Nuclepore (Pleasanton, California) polycarbonate membrane immediately before use.

\section{Standard curves}

The haptoglobin standard curve was prepared by double diluting a normal control plasma (Behringwerke, Marburg) from 1/50 to $1 / 1600$ in $0.9 \%$ w/v sodium chloride. A normal serum pool (Seward Immunostics) was similarly diluted from $1 / 25$ to $1 / 800$ for orosomucoid, from $1 / 100$ to $1 / 3200$ for alpha $a_{1}$ antitrypsin, and from $1 / 50$ to $1 / 1600$ for alpha $_{2}$ macroglobulin.

\section{Test sera}

These were diluted, in $0.9 \% \mathrm{w} / \mathrm{v}$ sodium chloride,

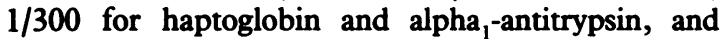
$1 / 200$ for orosomucoid and alpha ${ }_{2}$-macroglobulin.

Aliquots $(0.1 \mathrm{ml})$ of test sera or diluted standard were added to $1 \mathrm{ml}$ diluted antiserum or buffer (blank), mixed thoroughly by inversion, and incubated for one hour at room temperature before reading in the nephelometer according to the manufacturer's instructions.

\section{CREATINE KINASE MB ISOENZYME}

Creatine kinase MB isoenzyme (CK MB) was measured at $25^{\circ} \mathrm{C}$ using $\mathrm{N}$-acetyl cysteine-activated, immunological assay kits from Boehringer Corporation (London) Ltd. Precipath E control sera (Boehringer, Mannheim) containing known levels of CK MB isoenzyme were used to standardise the assay and the upper limit of normal was taken as $8 \mathrm{IU} / 1 .^{13}$
HUMAN CARDIAC TROPOMYOSIN

Serum cardiac tropomyosin was measured in triplicate by radioimmunoassay ${ }^{12}$ with an upper limit of normal of $5 \mathrm{ng} / \mathrm{ml}$.

\section{Results}

The mean $( \pm S D)$ values for 60 healthy adults for the five acute phase reactant proteins were as follows: $C$ reactive protein all values below $7 \mathrm{mg} / \mathrm{l}$, orosomucoid $0.8( \pm 0.3) \mathrm{g} / \mathrm{l}$, alpha ${ }_{1}$-antitrypsin $2.9( \pm 0.6) \mathrm{g} / \mathrm{l}$, haptoglobin 2.0 ( \pm 1.1$) \mathrm{g} / \mathrm{l}$, and alpha,macroglobulin $1.7( \pm 1.0) \mathrm{g} / \mathrm{l}$. The daily median serum levels for the 10 days after myocardial infarction in 17 patients are shown in Fig. 1 and 2. Haptoglobin and alpha ${ }_{1}$-antitrypsin levels rose to a peak (Fig. 1) at days 5 to 6, alpha ${ }_{2}$-macroglobulin did not reach a peak until day 8 , and orosomucoid showed little change. On day 4 (Table), these four proteins showed a rise in mean value after myocardial infarction of 33 to $127 \%$ above the mean level (expressed as $100 \%$ ) for healthy adults. In contrast, C-reactive protein reached a peak level (for both mean and median) on day 3 (Fig. 2), the mean level being $1570 \%$ above the upper limit of the controls (7 mg/l); the corresponding day 4 mean value (Table) was increased by $1357 \%$.

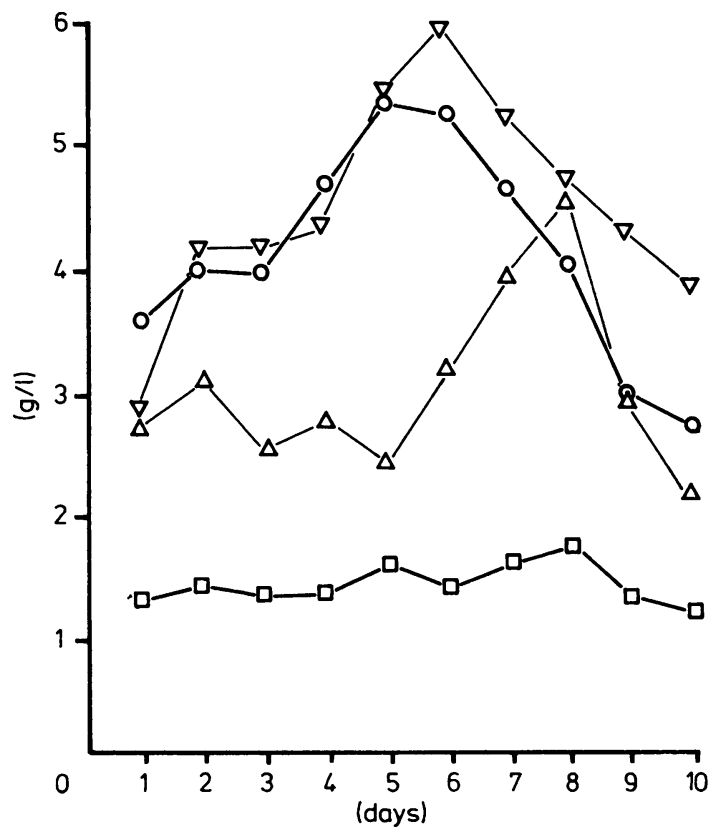

Fig. 1 Daily median values for four acute phase reactants (orosomucoid - $\square ; \alpha_{1}$-antitrypsin - $\nabla$; haptoglobin - $O ; \alpha_{2}-$ macroglobulin $-\triangle$ ) during the 10 days after myocardial infarction in 17 patients. 
Table Percentage change in mean serum level of five acute phase reactants after myocardial infarction (day 4), surgery (day 4), and infection (peak of days 1 to 3) in relation to mean (expressed as 100\%) for 60 healthy controls: number of patients studied in parentheses

\begin{tabular}{|c|c|c|c|c|c|c|}
\hline & \multirow{2}{*}{$\begin{array}{l}\text { Myocardial } \\
\text { infarction } \\
\text { (I7) }\end{array}$} & \multirow{2}{*}{$\begin{array}{l}\text { Hip } \\
\text { replacement } \\
\text { (33) }\end{array}$} & \multirow{2}{*}{$\begin{array}{l}\text { Hermia } \\
\text { repair } \\
(24)\end{array}$} & \multicolumn{3}{|l|}{ Infection } \\
\hline & & & & $\begin{array}{l}\text { Bacterial } \\
(31)\end{array}$ & $\begin{array}{l}\text { Viral } \\
(27)\end{array}$ & $\begin{array}{l}\text { Malaria } \\
\text { (14) }\end{array}$ \\
\hline $\begin{array}{l}\text { C-reactive protein } \\
\text { Orosomucoid } \\
\text { Alpha }_{1 \text {-antitrypsin }} \\
\text { Haptoglobin } \\
\text { Alpha }_{2} \text {-macroglobulin }\end{array}$ & $\begin{array}{l}+1357 \\
+101 \\
+\quad 33 \\
+\quad 127 \\
+\quad 77\end{array}$ & $\begin{array}{l}+2771 \\
+122 \\
+126 \\
+179 \\
+146\end{array}$ & $\begin{array}{l}+1001 \\
+\quad 90 \\
+\quad 34 \\
+\quad 72 \\
+\quad 34\end{array}$ & $\begin{array}{l}+2069 \\
+248 \\
+\quad 78 \\
+168 \\
+126\end{array}$ & $\begin{array}{l}+854 \\
+225 \\
+.18 \\
+.96 \\
+116\end{array}$ & $\begin{array}{l}+1580 \\
+188 \\
+\quad 31 \\
-\quad 18 \\
+132\end{array}$ \\
\hline
\end{tabular}

This large differential between the magnitude of the C-reactive protein response and those of the four other reactants was also found after hip replacement, herniorrhaphy, and infection (Table), with viral infection showing the smallest $\mathrm{C}$-reactive protein response relative to the others. Hip replacement caused the largest response for each of the five reactants. Haptoglobin, in patients with malaria, was the only reactant to fall below the mean normal value, presumably a consequence of haemolysis.

The time-scale and magnitude of the $\mathrm{C}$-reactive protein response after myocardial infarction was compared with those of CK MB and tropomyosin (Fig. 2). Raised serum levels of CK MB and tropomyosin are usually first detectable seven to eight hours after the onset of symptoms. ${ }^{12}$ Raised C-reactive protein levels of 25,110 , and $130 \mathrm{mg} / \mathrm{l}$ were detected in the first blood sample tested on admission (four hours from pain

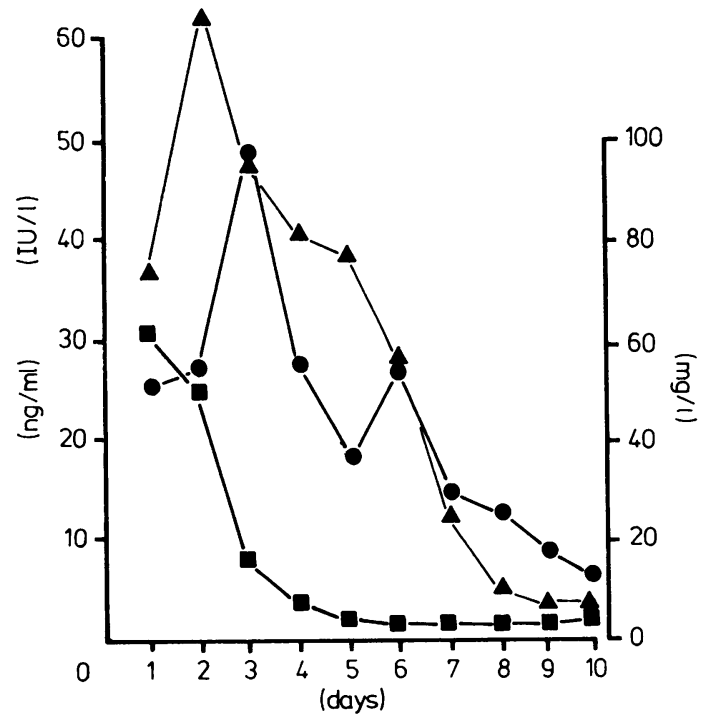

Fig. 2 Daily median values for $C$-reactive protein $(\bullet)$ in $\mathrm{mg} / \mathrm{l}$, creatine kinase $M B(\square)$ in IU/l, and cardiac tropomyosin $(\mathbf{\Delta})$ in $\mathrm{ng} / \mathrm{ml}$ after myocardial infarction in the same 17 patients as in Fig. 1 . onset), when CK MB was still normal, in three of the $\underset{\infty}{\stackrel{+}{+}}$ seven patients studied every two hours. There was no obvious explanation for this presumed pre-admission $\omega$ rise in serum $\mathrm{C}$-reactive protein. Two of the remaining $\mathrm{N}$ four patients, however, showed little or no increase in $\frac{\text { ㅇ }}{2}$ C-reactive protein during the first 24 hours when the CK MB level was already significantly raised. The $\bigcirc$ median values for all 17 patients, however, showed that $\stackrel{?}{\circ}$ $\mathrm{CK} \mathrm{MB}$ and tropomyosin reached their peak serum $\mathbb{\Phi}$ levels earlier than $\mathrm{C}$-reactive protein (Fig. 2). The $\overrightarrow{.}$ median serum CK MB level fell to normal within three $\infty$ days while tropomyosin fell to the upper limit of ? normal on day 8 , when the $C$-reactive protein level was still raised.

\section{Discussion}

Of the five acute phase reactant proteins, C-reactive $\vec{\overrightarrow{ }}$ protein was clearly the most responsive, and therefore 3 sensitive, to tissue damage caused by myocardial in- $\bar{P}$ farction. A similar situation was found within the four? day period after operation and acute infection, with the increase in mean C-reactive protein level averaging $1605 \%$ for all 146 patients studied (Table) compared with average increases of $162 \%$ for orosomucoid, $53 \% 3$

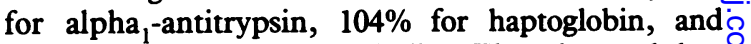
$105 \%$ for alpha 2 -macroglobulin. The observed late increase (day 8) in serum level of alpha ${ }_{2}-0$ macroglobulin is in contrast to earlier studies. ${ }^{14}$ is Apart from the smaller ( $854 \%$ ) C-reactive proteino increase in viral infection and the fall $(-18 \%)$ in haptoglobin in $\dot{P}$. vivax malaria, there was little evidence that the different types of tissue damage produced signi- $N$ ficantly different patterns of acute phase response. The స్ extent of tissue damage was probably the main deter- 0 minant of the peak serum level since the peak for each of the five reactants was between 1.4 to 4.3 times? greater after hip replacement than herniorrhaphy.

Earlier studies showed that C-reactive protein was 0 first detectable in serum one to two days after myo-o cardial infarction but an increase in serum level one to $\vec{\otimes}$ two hours after chest pain has been found more recentlyه্ by radial inmmunodiffusion assay. ${ }^{11}$ We found a pre- 
existing increase at four hours in three of seven patients and this occurred before any rise in CK MB. Study of a larger number of patients in the immediate postinfarction period is therefore indicated. Thereafter, the mean C-reactive protein level rose in all 17 patients to a peak on day 3. This compares with a peak level at 50.5 hours in a recent study of 33 patients in whom the peak CK MB level occurred at 14.8 hours. ${ }^{4}$

$A$ rise in serum $C$-reactive protein appears to be a sensitive test for myocardial necrosis and has been detected in 49 of 50 patients with acute infarction, ${ }^{9}$ in 100 patients with infarction whenever there were significant $Q$ wave electrocardiographic changes, ${ }^{8}$ and in all 33 patients with myocardial infarction studied serially. ${ }^{4}$ While these results indicate good sensitivity, it is necessary to exclude obvious alternative causes of a raised serum C-reactive protein level (for example surgery, infection, arthritis) if the test is to have acceptable specificity; if this is not done, specificity will be no better than that of the erythrocyte sedimentation rate. ${ }^{16}$ Specificity for myocardial necrosis does require to be investigated further since a few patients with congestive cardiac failure ${ }^{17}$ and unstable angina, ${ }^{11}$ but not angina associated with exercise testing, ${ }^{4}$ have shown small rises in serum level. The evidence that venous thrombosis causes a false positive rise in serum Creactive protein is, however, anecdotal. 681718 Out of 29 hip replacement patients, 25 had venogram confirmed leg vein thrombosis by day 4; with the exception of three patients with extensive thrombosis and very high C-reactive protein values $(275,310$, and 350 $\mathrm{mg} / \mathrm{l}$ ), all the others had $\mathrm{C}$-reactive protein values between 125 to $258 \mathrm{mg} / \mathrm{l}$ irrespective of the extent, or absence, of thrombosis. The $\mathrm{C}$-reactive protein level on day 8 also failed to differentiate patients according to extent or absence of thrombosis.

There is considerable potential value, for the assessment of myocardial necrosis, in studying proteins released from different tissue sites and with a different time scale of rise and fall in the plasma. The three proteins studied (CK MB, tropomyosin, and C-reactive protein) reached a peak level on days 1 to 3 and, while CK MB fell to normal within three days, both tropomyosin and $\mathrm{C}$-reactive protein showed a more protracted fall. Myosin, the major contractile protein, has been shown to have a similar time course of release, in patients with myocardial infarction, to that of $\mathrm{CK}$ $M B, 19$ though, in experimental infarction in the dog, the myosin level remains high for at least seven days. ${ }^{20}$ Tropomyosin, the regulatory myofibril protein, shows a slower rate of fall which may be affected by recurrent infarction. ${ }^{12}$ Parallel study of the similar half-lives of tropomyosin and $\mathrm{C}$-reactive protein in complicated and uncomplicated myocardial infarction would therefore be of particular value, in view of their different tissues of origin, in differentiating between cardiac and non- cardiac complications. As previously shown,${ }^{4}$ a raised $\mathrm{C}$-reactive protein level but normal CK MB in patients with chest pain of less than three days' duration indicates a pathological process other than myocardial infarction. Similarly, after the third day, when the CK MB level is no longer of diagnostic value, a raised C-reactive protein level but normal serum tropomyosin indicates non-cardiac tissue damage. After uncomplicated myocardial infarction, both C-reactive protein and tropomyosin should decline after the third day with similar half-lives, and failure of the fall in C-reactive protein to match that of tropomyosin therefore indicates an intercurrent non-cardiac complication which requires investigation. Serial monitoring of all three proteins thus provides maximal information for diagnostic purposes and in confirming post-infarct recovery; this approach is recommended for both clinical trial purposes and for individual patient care.

We thank Professor A M Geddes, Mr R A Hurlow, Dr A J F Page, and Professor W A Littler, and the surgeons of the Royal Orthopaedic Hospital for allowing us to study their patients; the Leukaemia Research Fund for financial support for the study on acute infection; and $\mathrm{Mr} \mathrm{A} \mathrm{J}$ George and $\mathrm{Mr} \mathrm{A} \mathrm{J}$ Davies for technical assistance.

\section{References}

1 Pepys MB. C-reactive protein fifty years on. Lancet 1981; i: $653-7$.

2 Rose PE, Johnson SA, Meakin M, Mackie PH, Stuart J. Serial study of C-reactive protein during infection in leukaemia. F ( ) lin Pathol 1981; 34: 263-6.

3 Gill CW, Bush WS, Burleigh WM, Fischer CL. An evaluation of a $\mathrm{C}$-reactive protein assay using a rate immunonephelometric procedure. Am if Clin Puthol 1981: 75: 50-5.

4 de Beer FC, Hind CRK, Fox KM, Allan RM, Maseri A, Pepys MB. Measurement of serum C-reactive protein concentration in myocardial ischaemia and infarction. $\mathrm{Br}$ Heart f 1982; 47: 239-43.

5 Löfström G. Comparison between the reactions of acute phase serum with pneumococcus C-polysaccharide and with pneumococcus type 27. Brf Exp P'athol 1944; 25: 21-6.

6 Kroop IG, Shackman NH. Level of C-reactive protein as a measure of acute myocardial infarction. Proc Soc Exp Biol Med 1954; 86: 95-7.

7 Kroop IG, Shackman NH. The C-reactive protein determination as an index of myocardial necrosis in coronary artery disease. Am 7. Med 1957; 22: 90-8.

8 Kozonis MC, Gurevin I. The value of the $\mathrm{C}$-reactive protein determination in coronary artery disease. Ann Intern Med 1957; 46: 79-85.

9 Levinger EL, Levy H, Elster SK. Study of C-reactive protein in the sera of patients with acute myocardial infarction. Ann Intern Med 1957; 46: 68-78. 
10 Johansson BG, Kindmark C-O, Trell EY, Wollheim FA. Sequential changes of plasma proteins after myocardial infarction. Scand f Clin Lab Invest 1972; 29, suppl 124: 117-26.

11 Kushner I, Broder ML, Karp D. Control of the acute phase response. Serum C-reactive protein kinetics after acute myocardial infarction. $\mathcal{F}$ Clin Invest 1978; 61: 235+2 .

12 Cummins P, McGurk B, Littler WA. Radioimmunoassay of human cardiac tropomyosin in acute myocardial infarction. Clin Sci 1981; 60: 251-9.

13 Surtees SJ, Bastable MD, Gietzen TW, et al. A biochemical and clinical comparison of two commercially available creatine kinase iso-enzyme $\mathrm{MB}$ assay kits suitable for use in the routine medical laboratory. Ann Clin Biochem 1979; 16: 197-204.

14 Crockson RA, Payne CJ, Ratcliff AP, Soothill JF. Time sequence of acute phase reactive proteins following surgical trauma. Clin Chim Aita 1966; 14: 435-4l.

15 Werner $M$. Serum protein changes during the acute phase reaction. Clin Chım Aita 1969; 25: 299-305.
16 Kenny MW, Worthington DJ, Stuart J, et al. Efficiency of haematological screening tests for detecting disease. Clin Lab Haematol 1981; 3: 299-305.

17 Hedlund P. Clinical and experimental studies on C reactive protein (acute phase protein). Acta Med Scand 1961; suppl 361: 1-71.

18 Roantree RJ, Rantz LA. Clinical experience with the C-reactive protein test. Arch Intern Med 1955; 96: 674-82.

19 Trahern CA, Gere JB, Krauth GH, Bigham DA. Clinical o assessment of serum myosin light chains in the diagnosis of acute myocardial infarction. Am $\mathcal{F}$ Cardiol 1978; 41: 64l-5.

20 Yazaki Y, Nagai R, Yamaoki K, Ueda S. Myocardial infarction size from serum cardiac myosin light chain; clinical and experimental studies. 7 Mol Cell Curdiol 1980; 12, suppl 1: 183.

Requests for reprints to Professor J Stuart, 舁 Department of Haematology, Medical School, 음 University of Birmingham, Birmingham B15 2TJ. 